\title{
KESULITAN MAHASISWA DALAM PEMBELAJARAN DARING PADA MASA PANDEMI COVID-19
}

\author{
Etty Ratnawati ${ }^{1}$, Aditya Putra Utama ${ }^{2}$ \\ IAIN Syekh Nurjati Cirebon ${ }^{1,2}$ \\ ettyratnawati@syekhnurjati.ac.id; putraadityavb96@gmail.com
}

\begin{abstract}
ABSTRAK
Tujuan dari penelitian ini adalah untuk menjabarkan kesulitan-kesulitan yang di hadapi mahasiswa IAIN Syekh Nurjati Cirebon dalam pembelajaran daring selama masa pandemi COVID-19. Jenis penelitian ini adalah penelitian deskriptif kualitatif. Subjek pada penelitian ini adalah mahasiswa IAIN Syekh Nurjati Cirebon. Wawancara tidak terstruktur merupakan alat pengumpulan data yang dipergunakan untuk mengumpulkan data pada penelitian ini. Metode jenis ini memungkinkan subjek untuk benar-benar menyuarakan apa yang dipikirkannya selama pembelajaran. Hasil dari penelitianini menunjukkan bahwa terdapat beberapa kesulitan yang dihadapi mahasiswa dalam pembelajaran daring yang dapat digolongkan menjadi kesulitan teknis, kesulitan adaptasi dan ketidaksiapan pengajar. Agar dapat teratasi kesulitan-kesulitan tersebut, para pengajar perlu melakukan perubahan strategi pembelajaran yang dapat menunjang percepatan adaptasi mahasiswa dalam pembelajaran daring. Disamping itu, pengajar juga diharapkan dapat meningkatkan kemampuan TIK-nya sehingga bisa menggunakan media pembelajaran daring yang lebih bervariasi sesuai dengan kesulitan teknis yang dihadapi.
\end{abstract}

Kata Kunci : Pandemi Covid-19, Pembelajaran Daring, Kesulitan Belajar

\section{ABSTRACT}

The purpose of this study was to describe the difficulties faced by students of IAIN Syekh Nurjati Cirebon in online learning during the COVID-19 pandemic. This type of research is a qualitative descriptive study. The subjects in this study were students of IAIN Syekh Nurjati Cirebon. Unstructured interviews were used as the instrument used to collect data in this study. This type of interview allows the subject to really voice what he is thinking during the lesson. The results of the analysis show that students face several difficulties which are classified into technical difficulties, adaptation difficulties and teacher unpreparedness. To overcome these difficulties, it is necessary to develop learning strategies that can support the acceleration of student adaptation in online learning. In addition, teachers (lecturers) must also improve their ICT skills so that they can use more varied online learning media according to the technical difficulties faced.

Keywords: Covid-19 Pandemic, Learning Difficulties, Online Learning 


\section{A. PENDAHULUAN}

Di dunia saat ini sedang marak-maraknya wabah coronavirus. Virus inimerupakan keluarga besar virus yang dapatmenimbulkan penyakit mulai dari gejala ringan sampai berat. COVID-19 (Coronavirus Diseases 2019) adalah penyakit jenis baru yang belum pernah diidentifikasi sebelumnya pada manusia. Tanda dan gelaja umum infeksi virus ini antara lain gejala gangguan pernapasan akut seperti demam, batuk, dan sesak napas. Masa inkubasi rata-rata 5-6 hari dengan masa inkubasi terpanjang 14 hari.

WHO pada tanggal 30 Januari 2020 telah menetapkan COVID-19 sebagai kedaruratan kesehatan masyarakat yang meresahkan dunia. Di Indonesia berdasarkanlaporan pada tanggal 2 Maret 2020, terdapat kasus konfirmasi COVID-19 sebanyak 2 kasus. Kasusterkonfirmasi virus inisemakinbertambah, dimana sampai dengan tanggal 16 Maret 2020 ada 10 orang yang dinyatakan positif corona (Yurianto dkk, 2020). Dengan munculnya virus COVID-19 saat initernyataberdampak bagi seluruh aspekkehidupanmasyarakat Indonesia. Sebagaimana yang diberitakandalamKompaspadatanggal28Maret2020, bahwa dampak virus COVID-19 terjadi diberbagai bidang, baik sosial, ekonomi, pariwisata maupun pendidikan.

Wabah Corona Virus Diseases 2019 (COVID-19) initelah melanda 215 negara di dunia. Hal ini memberikan tantangan tersendiri bagi lembaga pendidikan di Indonesia, khususnya Perguruan Tinggi. Menteri Pendidikan dan Kebudayaan Republik Indonesia, pada tanggal 24 maret 2020 mengeluarkan Surat Edaran Nomor 4 Tahun 2020 Tentang Pelaksanaan Kebijakan Pendidikan Dalam Masa Darurat Penyebaran COVID-19.Dalam Surat Edaran tersebut dijelaskan, bahwa kegiatan belajar mengajardilaksanakan di rumah melalui pembelajaran daring/jarak jauh atau SFH (Study Frome Home)yang dilaksanakan untuk memberikan pengalaman belajar yang bermakna bagi siswa.

Salah satu kampus yang harus mengikuti peraturan tersebut adalah IAIN Syekh Nurjati Cirebon. Satu-satunya Perguruan Tinggi IslamNegeri di Cirebon ini menerapkan pembelajaran daring berdasarkan edaran Dirjen Pendidikan Islam Kemenag nomor B-574.1/DJ.I/HM.0110312020 tentang Kesiapsiagaan dalam 
upaya Pencegahan Penyebaran Penyakit Pneumonia (Panjiprayitno, 2020). Penerapan pembelajaran SFH (Study From Home)tersebut mengharuskan para dosen di lingkungan IAIN Syekh Nurjati Cirebon melakukan pembelajaran secara daring sebagai alternatif pengganti perkuliahan tatap muka. Meski dilaksanakan secara daring, pembelajaran haruslah tetap dapat meningkatkan minat mahasiswa untuk mengikutinya.

Pembelajaran daring atau E-learning ialah model pembelajaran terbaru dalam dunia pendidikan yang mampu menanggulangi keterbatasan ruang yang selama ini menjadi kelemahan model pembelajaran konvensional (Hasan, 2020). Akan tetapi perubahan penggunaan model pembelajaran yang terlalu tiba-tiba ini bisa berdampak pada menurunnya minat mahasiswa dalam mengikuti pembelajaran. Padahal, minat merupakan perangkat motivasi utama dalam membangkitkan gairah belajar mahasiswa dalam kurun waktu tertentu (Friantini \& Winata, 2019).

Menurut Moore, Dickson-Deane, \& Galyen (2011) yang dikutipAli Sadikin,dkk (2020)mengemukakan, bahwa pembelajaran daring merupakan pembelajaran yang menggunakan jaringan internet dengan aksesibilitas, konektivitas, fleksibilitas, dan kemampuan untuk memunculkan berbagai jenis interaksi pembelajaran. Penelitian yang dikakukan oleh Zhang et al., (2004) menunjukkan, bahwa denganmemanfaatkan internet dan teknologi multimedia dapat merombak cara penyampaian pengetahuan, dan jugadapat menjadi alternatif pembelajaran yang dilaksanakan dalam kelas tradisional. Selainitu, Kuntarto (2017) jugamengemukakan, bahwa pembelajaran daring adalah pembelajaran yang mampu mempertemukan mahasiswa dan dosen untuk melaksanakan interaksi pembelajaran dengan bantuan internet.Dimanadalampelaksanaannya memerlukan dukungan perangkat-perangkat mobile, seperti smarphone atau telepon adroid, laptop, komputer, tablet, dan iphone yang dapat dipergunakan untuk mengakses informasi kapan saja dan dimana saja (Gikas \& Grant, 2013).

Perguruan tinggi pada masa WFH perlu melaksanakan penguatan pembelajaran secara daring (Darmalaksana, 2020). Pembelajaran secara daring telah menjadi tuntutan dunia pendidikan sejak beberapa tahun terakhir ( $\mathrm{He}, \mathrm{Xu}, \&$ Kruck, 2014).Apalagi di era revolusi industry 4.0 ini. Pembelajaran ini merupakan 
inovasi pendidikan untuk menjawab tantangan akan ketersediaan sumber belajar yang variatif.Pembelajaran daring sangat mengandalkan kemajuan teknologi informasi, tak terpungkuri mahasiswa harus menghadapi kendala dan kesulitan dalam pembelajaran daring.

Ketersediaan perangkat yang mendukung untuk pembelajaran daring bagi mahasiswa di daerah-daerah Indonesia ini juga masih terbatas tak terkecuali di Cirebon. Tidak jarang mahasiswa yang harus meminjam laptop temannya untuk mengikuti pembelajaran daring. Terkait hal, pemanfaatan smartphone menggantikan peran komputer atau laptop, cukup membantu mahasiswa. Namun, kendala kuota internet yang tidak mencukupi juga menyulitkan mereka. Tidak jarang mahasiswa harus datang ke café-café atau bahkan ke kampus hanya agar tersambung dengan sinyal wifi. Ditengah pandemi COVID-19 seperti sekarang, tentu hal ini menyulitkan dan mengancam kesehatan mereka. Bukan hanya mahasiswa, tetapi dosen pun membutuhkan adaptasi di masa darurat kesehatan saat ini. Meski tidak dapat bertatap muka, dosen harus berpikir keras agar pembelajaran yang disampaikan tetap dapat menarik minat mahasiswa mengikutinya.

Berdasarkan berbagai kendala dan permasalahan yang telah dipaparkan di atas, peneliti menilai perlu untuk mengekspoitasinya lebih dalam. Penelitian ini bertujuan untuk dapat menjabarkan kesulitan-kesulitan yang dihadapi mahasiswaInstitut Agama Islam Negeri Syekh Nurjati Cirebon dalam perkuliahan yang dilaksanakan secara daring selama masa pandemi COVID-19.

\section{B. METODE PENELITIAN}

Metodepenelitianiniadalahkualitatif, yaitumetode penelitian yang digunakan untuk meneliti obyek yang bersifat alamiah, di mana peneliti dalam hal ini merupakan instrumen kunci dari penelitian tersebut. Teknik pengumpulan data dari metode kualitatif dilakukan secara trianggulasi, analisis data bersifat induktif, serta lebih menekankan makna dari pada generalisasi (Sugiyono,2015). Menurut Moleong (2012) metode penelitian kualitatif adalah penelitian yang menghasilkan data deskriptif berupa kata-kata lisan dari orang-orang yang perilakunya dapat diamati oleh peneliti. 
Penelitian ini merupakan penelitian kualitatif deskriptif. Penelitian kualitatif deskriptif adalah penelitian yang bertujuan mendesripsikan/menjabarkan peristiwa yang terjadi pada subjek penelitian secara mendalam. Pada penelitian ini peristiwa yang diamati dan akan dijabarkan adalah kesulitan-kesulitan yang dihadapi mahasiswa pada saat mengikuti pembelajaran daring. Kesulitan-kesulitan yang muncul kemudian dikelompokkan menjadi 2 (dua), yaitu kesulitan teknis dan kesulitan adaptasi mahasiswa. Pengelompokan ini didesain untuk memfokuskan tujuan penelitian.

Menurut Moleong (2012) subjek penelitian adalah sumber informasi pada penelitian yang dibutuhkan untuk pengumpulan data. Subjek dari penelitian ini mahasiswa IAIN Syekh Nurjati Cirebon yang sedang melaksanakan pembelajaran daring. Subjek penelitian dipilih berdasarkan teknik Snowball Sampling, yaitu teknik pengambilan sampel yang mula-mula jumlahnya kecil, kemudian diambil lagi sampel berikutnya, begitu seterusnya sehingga sampel semakin banyak (Sugiyono, 2013). Pemilihan sendiri berakhir jika sudah terjadi pengulangan. Hal ini dikarenakan, penambahan jumlah sampel dimaksudkan untuk memperluas informasi, jika sudah tidak ada lagi informasi yang dapat dijaring maka penarikan sampel sudah dapat diakhiri. Jadi, kuncinya ialah bila sudah terjadi pengulangan informasi dengan kata lain informasi yang diperoleh telah jenuh, maka pengambilan sampel sudah harus dihentikan (Moloeng, 2007). Proses pengumpulan data dihentikan pada saat sudah tidak lagi ditemukan informasi baru atau terjadi pengulangan informasi yang didapatkan.

Wawancara merupakan teknik pengumpulan data dengan jalan tanya jawab sepihak yang dilakukan secara sistematis dan berlandaskan kepada tujuan penelitian (Lerbin, 1992 dalam Hadi,2007). Tanya jawab 'sepihak' berarti bahwa pegumpulan data yang aktif bertanya sementara pihak yang ditanya aktif memberikan jawaban atau tanggapan. Dalam penelitian ini teknik wawancara yang digunakan adalah wawancara tidak terstruktur. Teknik ini, dalam wawancara kualitatif, mengacu pada jenis wawancara di mana peneliti mengajukan pertanyaan yang sifatnya umum dan jumlahnya minimal. Adapun pertanyaan yang diajukan hanya berupa topik umum untuk membantu memfokuskan responden. 
Ada perbedaan dalam pengumpulan data penelitian ini karena disesuaikan dengan keadaan saat penelitian dilaksanakan. Pemerintah memerintahkan untuk menerapkan protokol kesehatan, yaitu tidak berkerumun, melakukan pembatasan sosial (social distancing) dan menjaga jarak fisik (physical distancing). Maka dari itu, wawancara tidak dilakukan secara tatap muka akan tetapi dilakukan secara tidak langsung atau dibantu dengan media sosial yang bisa menghubungkan peneliti dengan responden. Keadaan ini dimaksud untuk tetap menjaga diri dan mematuhi protokol kesehatan dan melawan COVID-19.

Subyek dalam penelitian ini adalah para mahasiswa IAIN Syekh Nurjati Cirebon Jurusan Tadris IPS angkatan 2017, 2018, dan 2019. Didapatkan 12 orang subjek penelitian, yaitu 4 orang mahasiswa angkatan 2017, 4 orang mahasiswa angkatan 2018, dan 4 orang mahasiswa angkatan 2019, Dari jumlah tersebut, 8 orang mahasiswa berjenis kelamin laki-laki dan 4 orang mahasiswa berjenis kelamin perempuan. Aspek-aspek yang ditanyakan dalam wawancara adalah: (1) Respon mahasiswa mengenai kesiapan pembelajaran daring; (2) Kendala teknis dalam pelaksanaan pembelajaran daring; (3) Adaptasi mahasiswa dengan metode pembelajaran daring.

\section{HASIL DAN PEMBAHASAN}

\section{Hasil Wawancara Tidak Terstruktur mengenai Kesulitan Mahasiswa dalam Pembelajaran Daring}

Pandemi COVID-19 di Indonesia merupakan bagian dari pandemi penyakit koronavirus 2019 (COVID-19) yang sedang berlangsung di seluruh dunia. Di Indonesia, kasus positif COVID-19 pertama kali dideteksi pada tanggal 2 Maret 2020, dimana diketahui ada dua orang terkonfirmasi tertular dari seorang warga negara Jepang (Rebecca,2/03/2020). Dilansir dari Bangkok Post 9 April 2020, bahwa pandemi sudah menyebar ke 34 provinsi dengan DKI Jakarta, Jawa Timur dan Jawa Barat sebagai provinsi paling terpapar virus corona di Indonesia.

Berdasarkan bukti ilmiah, COVID-19 dapat menular dari manusia ke manusia melalui percikan batuk/bersin (droplet), tidak melalui udara. Orang yang kontak erat dengan pasien COVID-19 termasuk yang merawat pasien 
COVID-19 adalah orang yang paling berisiko tertular penyakit ini. Karena itu kita perlu menerapkan protokol kesehatan untuk mencegah penyebaran infeksi, yaitu selalu mencuci tangan secara teratur menggunakan sabun dan air bersih, menerapkan etika batuk dan bersin, menghindari kontak secara langsung dengan ternak dan hewan liar serta menghindari kontak dekat dengan siapapun yang menunjukkan gejala penyakit pernapasan seperti batuk dan bersin. Selain itu, menerapkan Pencegahan dan Pengendalian Infeksi (PPI) saat berada di fasilitas kesehatan terutama unit gawat darurat (dinkes kabupaten bantul, 8/04/2020).

Wabah Corona Virus Diseases 2019 (COVID-19) ini telah melanda 215 negara di dunia. Hal ini memberikan tantangan tersendiri bagi lembaga pendidikan di Indonesia, khususnya Perguruan Tinggi. Menteri Pendidikan dan Kebudayaan Republik Indonesia, pada tanggal 24 maret 2020 mengeluarkan Surat Edaran Nomor 4 Tahun 2020. Dalam surat Edaran tersebut dijelaskan,bahwa kegiatan belajar mengajar dilaksanakan di rumah melalui pembelajaran daring/jarak jauh atau SFH (Study Frome Home) untuk memberikan pengalaman belajar yang bermakna bagi siswa.

Salah satu kampus yang harus mengikuti peraturan tersebut adalah IAINSyekh Nurjati Cirebon. Penerapan pembelajaran SFH (Study From Home) tersebut mengharuskan para dosen di lingkungan IAIN Syekh Nurjati Cirebon melaksanakan perkuliahan secara daring sebagai alternatif pengganti perkuliahan tatap muka. Meski dilaksanakan secara daring, pembelajaran haruslah tetap dapat meningkatkan minat mahasiswa untuk mengikutinya. Pembelajaran daring merupakan sistem pembelajaran yang dilakukan dengan tidak bertatap muka langsung, tetapi menggunakan platform yang dapat membantu proses belajar mengajar yang dilakukan meskipun jarak jauh. Tujuan dari adanya pembelajaran daring ialah memberikan layanan pembelajaran bermutu dalam jaringan yang bersifat masif dan terbuka untuk menjangkau peminat ruang belajar agar lebih banyak dan lebih luas (Sofyana \& Abdul, 2019). 
Pembelajaran daring atau E-learning ialah model pembelajaran terbaru dalam dunia pendidikan yang mampu menanggulangi keterbatasan ruang yang selama ini menjadi kelemahan model pembelajaran konvensional (Hasan, 2020). Akan tetapi perubahan penggunaan model pembelajaran yang terlalu tiba-tiba ini bisa berdampak pada menurunnya minat mahasiswa dalam mengikuti pembelajaran. Padahal, minat merupakan perangkat motivasi utama dalam membangkitkan gairah belajar mahasiswa dalam kurun waktu tertentu (Friantini \& Winata, 2019).

Perkembangan teknologi informasi memiliki pengaruh besar terhadap perubahan dalam setiap bidang, diantaranya bidang pendidikan. Sekolah sebagai salah satu lembaga pendidikan juga memanfaatkan teknologi dalam kegiatan proses belajar mengajar, yang tadinya menggunakan cara konvensional berubah ke modern. Gheytasi, Azizifar \& Gowhary (dalam Khusniyah dan Hakim, 2019) dalam penelitiannya menyebutkan, bahwa dengan adanya teknologi memberikan banyak pengaruh positif terhadap pembelajaran. Internet telah dipadukan menjadi sebuah media yang digunakan untuk melengkapi kegiatan pembelajaran (Martins,2015).

Pembelajaran daring sangat mengandalkan kemajuan teknologi informasi, tak terpungkiri mahasiswa harus menghadapi kendala dan kesulitan belajar dalam pembelajaran daring. Sebagaimana yang dikemukakan Dalyono (1997), bahwa kesulitan belajar menyebabkan siswa tidak dapat belajar sebagaimana mestinya. Hal ini juga bias berpengaruh terhadap prestasi belajar yang rendah, bahkan dapat menyebabkan suatu keadaan yang sulit dan mungkin menimbulkan suatu keputusasaan sehingga memaksakan seorang siswa untuk berhenti di tengah jalan.

Ketersediaan perangkat yang mendukung untuk pembelajaran daring bagi mahasiswa di daerah-daerah Indonesia ini juga masih terbatas tak terkecuali di Cirebon. Tidak jarang mahasiswa yang harus meminjam laptop temannya untuk mengikuti pembelajaran daring. Terkait hal, pemanfaatan smartphone menggantikan peran komputer atau laptop, cukup membantu mahasiswa. Namun, kendala kuota internet yang tidak mencukupi juga menyulitkan 
mereka. Tidak jarang mahasiswa harus datang ke café-café atau bahkan ke kampus hanya agar tersambung dengan sinyal wifi. Ditengah pandemi COVID19 seperti sekarang, tentu hal ini menyulitkan dan mengancam kesehatan mereka. Bukan hanya mahasiswa, tetapi dosen pun membutuhkan adaptasi di masa darurat kesehatan saat ini. Meski tidak dapat bertatap muka, dosen harus berpikir keras agar pembelajaran yang disampaikan tetap dapat menarik minat mahasiswa mengikutinya.

Penelitian ini bertujuan untuk dapat menjabarkan kesulitan-kesulitan yang dihadapi mahasiswa IAIN Syekh Nurjati Cirebon dalam perkuliahan yang dilaksanakan secara daring selama masa pandemi COVID-19, dengan meninjau dari aspek Kesulitan Teknis, Kesulitan Adaptasi Mahasiswa, dan Ketidaksiapan Dosen melalui wawancara tidak terstruktur terhadap mahasiswa IAIN Syekh Nurjati Cirebon.

Wawancara Tidak terstruktur dilakukan dengan memperhatikan pelaksanaan teknik snawball sampling. Beberapa Mahasiswa IAIN Syekh Nurjati Cirebon sebagai responden diwawancarai satu per satu. Bentuk pengumpulan data ini kemudian dihentikan setelah didapati terjadi pengulangan informasi atau muncul informasi yang sama. Data berikut yang dijabarkan adalah data yang sudah terkumpul dari 4 (empat) responden. Hal ini dikarenakan pada wawancara ke-5 dan seterusnya, informasi yang didapat serupa dengan informasi/data yang didapat dari keempat mahasiswa pertama.

\section{Kesulitan Teknis}

Keberhasilan peserta didik dalam belajar diantaranya dipengaruhi oleh media tekonologi yang digunakan. Sebagaimana yang dikemukakan Anggrawan (2019) bahwa, penggunaan smartphone dan laptop dalam pembelajaran daring dapat meningkatkan hasil belajar peserta didik. Namun terkadang mereka mengalami kesulitan ketika memanfaatkan media tersebut. Seperti yang dikemukakan Pangondian, R.A, dkk (2019), banyak kelebihan penggunaan teknologi informasi dan komunikasi dalam pelaksanaan pembelajaran daring diantaranya adalah tidak terikat ruang dan waktu. Akan 
tetapi penggunaan teknologi tersebut tidak luput dari masalah peralatan yang tidak terduga atau biasa disebut kendala teknis.

Peneliti memberikan pertanyaan melalui wawancara tidak terstruktur dengan mahasiswa sebagai responden mengenai kesulitan teknis yang dialami mereka pada saat mengikuti pembelajaran daring.

Tabel 1. Hasil Wawancara Tentang Kesulitan Teknis Mahasiswa

Responden 1: "selama masa pandemi, masalah yang saya alami saat kuliah online adalah sinyal internet kurang karena saya ada di kampung dan banyak habiskan kuota untuk mencari tugas dengan internet dan membuat video"

Responden 2: "kendala yang saya hadapi adalah kurangnya paket internet, jaringan internet yang lelet, dan karena ada pandemi saya memutuskan untuk bekerja membantu orang tua dan sekarang saya jadi susah mengatur waktu dengan pekerjaan itu"

Responden 3:"internet dikampung saya lelet, kadang saya juga harus numpang wifi di kampus untuk ngirim tugas yang ukuran MB nya besar"

Responden 4: "kuliah online kadang menyulitkan saya, karena laptopnya kadang lelet jadi harus pakai HP, buka web diHP dan mencatat tugas juga kadang di HP”

Dapat diperhatikan pada hasil wawancara kesulitan teknis diatas, Responden pertama mengungkapkan kesulitannya yaitu (1) Kurangnya sinyal internet dirumah/kampungnya. Ini adalah kendala yang berkaitan dengan masa pandemi COVID-19 ini. Sebagian mahasiswa mengakses internet menggunakan layanan selular, dan sebagian kecil menggunakan layanan $\mathrm{WiFi}$. Selama masa Study from Home (SFH), mahasiswa banyak yang memilih untuk pulang ke kampungnya. Mengingat mereka berasal dari berbagai daerah yang kondisi geografisnya mempunyai macam-macam kendala mengenai kekuatan sinyal internet dalam masa pembelajaran daring.Jelas ini menjadi salah satu kesulitan yang mengganggu mahasiswa dalam mengikuti pembelajaran daringkarena metode pembelajaran ini sangat bergantung pada jaringan internet.SejalandenganpendapatAstutidanFebrian (2019) yang menyatakan, 
bahwa pembelajaran daring memiliki kelemahan ketika layanan internet lemah, dan intruksi dosen yang kurang dipahami oleh mahasiswa. (2) Cepat terkurasnya kuota internet. Kesulitan yang juga sering diungkapkan mahasiswa adalah masalah cepat habisnya paket data atau kuota internet untuk mengakses informasi. Hal ini dikarenakan banyaknya materi dan tugas yang diberikan pada pembelajaran daring sehingga mahasiswa juga harus banyak mencari informasi, mengunduh materi dan mengunggah data yang berkaitan dengan tugas kuliah mereka. Hal ini juga menjadi tantangan mahasiswa dan orang tua mereka dalam mengeluarkan dana yang cukup untuk membeli kuota internet bagi keberlangsungan pembelajaran. Tak jarang mahasiswa harus rela melanggar peraturan keluar rumah untuk mencari layanan internet gratis di kampus atau tempat-tempat lainnya.

Responden Kedua kemudian mengungkapkan kesulitan yang dihadapinya yaitu: (1) Jaringan yang lambat, meskipun rumahnya terjangkau sinyal internet ternyata jaringannya tetap tidak bisa diandalkan.Produktivitas mahasiswa dalam mengerjakan tugas kuliah atau mengikuti perkuliahan online menjadi lamban jika jaringan internet mereka lambat. Permasalahan seperti ini umum ditemui terutama di daerah-daerah perbatasan dan daerah pegunungan. (2) Kesulitan mengatur waktu, menurut Responden Kedua karena ia ada di rumah, maka ia memutuskan untuk bekerja membantu orangtuanya. Ia pun pada akhirnya kesulitan membagi waktu antara membantu orang tuanya dan mengikuti perkuliahan. Kondisi pandemi saat ini juga mempengaruhi perekonomian masyarakat indonesia. Banyak juga dari mahasiswa yang memiliki pekerjaan diluar kegiatan akademik demi keberlangsungan hidup mereka ini menjadi kendala bagi mereka untuk mengatur waktu antara mengerjakan tugas kuliah dan pekerjaan lainnya.

Responden Ketiga mengungkapkan kesulitannya, yaitu susahnya dalam mengirim tugas dalam ukuran data yang besar sehingga harus melanggar aturan kesehatan dan datang kekampus agar dapat mengunggah tugasnya. Kasus ini terjadi karena permasalahan yang sama dengan Responden Kedua kurangnya kuota internet sehingga Responden Ketiga terpaksa melanggar 
protokol kesehatan pergi ke kampus untuk menggunakan wifi dan kuota internetpun bisa terjaga untuk tugas kuliah online yang lain.

Responden Keempat kesulitan yang ia hadapi adalah terbatasnya perangkat yang ia miliki untuk menunjang dalam mengikuti pembelajaran daring. Pada mata kuliah yang memerlukan penjelasan yang lebih jelas dan konkrit, perlu ditunjang dengan media yang memadai agar bisa meningkatkan minat belajar mahasiswa. Keadaan sosial mahasiswa yang berbeda-beda memungkinkan tidak semua mahasiswa dapat dengan mudah mengakses informasi melalui perangkat yang memadai untuk bahan pembelajaran daring di perguruan tinggi karena mahasiswa IAIN Syekh Nurjati berasal dari latar belakang yang berbeda-beda tidak semua memiliki kelengkapan perangkat penunjang belajar daring di.masa pandemi COVID-19.

\section{Kesulitan Adaptasi Mahasiswa}

Wawancara tidak terstruktur bagian ini peneliti menanyakan kesiapan mahasiswa menghadapi pembelajaran jarak jauh atau daring dimasa pandemi COVID-19. Menilai metode daring secara tiba-tiba dilaksanakan seiring munculnya virus corona.

Tabel 2. Hasil Wawancara Tentang Adaptasi Mahasiswa

Responden 1: "selama kuliah online yang saya rasakan kurang siap, merasa tidak terbiasa tidak masuk kelas, mengerjakan tugas jadi malas karena saya ada dirumahbanyak disuruh-suruh orangtua, tugas kuliah online juga kayaknya lebih banyak jadi tambah susah mengerjakannya"

Responden 2: "Sebenarnya saya tidak siap menghadapi kuliah online. Kondisi yang melarang saya kekampus membuat saya sulit berkonsentrasi belajar dirumah. Membagi waktu juga jadi sulit, saya jadi lebih banyak menghabiskan waktu untuk bekerja ketimbang belajar materi dari dosen dan menyelesaikan tugas"

Responden 3: "sebenarnya masih belum siap kalau harus kuliah online, tapi mau tidak mau karena ini wajib selama masa pandemi ini jadi terpaksa diikuti walaupun sulit, apalagimaterinya juga susah"

Responden 4: "saya kurang siap karena metode ini baru terdengar ditelinga saya dan jujur saya lebih menyukai tatap muka karena saya orangnya suka sosialisasi rasanya 
bosan jika kuliah hanya lewat handphone dan laptop lebih seru tatap muka bertemu kawan-kawan"

Padabagian wawancara tentang kesulitan adaptasi mahasiswa dapat dilihat bahwa datadi ambil dari 4 mahasiswa sebagai responden. Hal ini disebabkan karena pada responden ke-5dan seterusnya telah terjadi pengulangan informasi/data sehingga hanya data dari 4 responden awal yang kemudian dianalisis.

Responden 1 mengungkapkan kesulitan adaptasi yang di hadapinya yaitu (1) tidak terbiasa dengan kelas online, ia lebih memilih tatap muka seperti biasa. Menurut Responden pertama ia tidak terbiasa dengan kelas online karena sudah lama ia melakukan pembelajaran secara tatap muka langsung didalam kelas. Daring adalah hal yang sangat baru untuk sebagian mahasiswa (2) keadaan dirumah yang tidak kondusif baginya untuk mengikuti pembelajaran daring. Perkuliahan yang dilakukan secara daring menjadikan mahasiswa melakukan aktivitas akademik di rumah masing-masing yang mana kita tidak pernah mengetahui bagaimana kondisi lingkungan yang ada di rumah apakah mendukung atau justru seperti responden pertama yang mengeluhkan keadaan rumahnya yang tidak kondusif saat ia menjalankan kuliah online. Menurut tempo, 2/06/2020 ada 3 hal yang mempengaruhi kondisi psikologis anak pada saat belajar di rumah: a. Cara orang tua berinteraksi dengan anak; b. Interaksi sesama anggota keluarga; c. Kondisi Rumah dalam hal penataan dan kebersihan. (3) merasa bahwa tugas pada kelas online lebih banyak dibanding di kelas tatap muka. Tantangan pembelajaran daring bukan hanya dirasakan mahasiswa saja tetapi kalangan pengajar seperti dosenpun harus berpikir bagaimana menyiapkan materi-materi kuliah online dan bagaimana mahasiswa dapat tergugah minat belajarnya dengan menggali informasi melalui tugastugas yang diberikan. Pertemuan yang terbatas menjadikan mahasiswa menilai dosen jauh lebih banyak memberikan tugas saat pembelajaran daring dibanding saat perkuliahan tatap muka.

Selanjutnya menurut Responden kedua, ia berhadapan dengan (1) sulitnya berkonsentrasi saat belajar di rumah. Responden kedua merasa kondisi yang 
tidak memperbolehkannya pergi ke kampus menjadikan kurangnya konsentrasi dalam mengikuti kuliah online.Faktor non-teknis seperti tidak mengerti dengan materi perkuliahan, pembelajaran yang monoton, mengantuk, jenuh dan lain sebagainya memicu kurangnya konsentrasi mahasiswa saat pembelajaran daring. (2) kesulitan membagi waktu antara bekerja dan mengikuti pembelajaran daring. Keadaan pandemi seperti ini memaksa Responden kedua untuk mencari kerja demi keberlangsungan hidup akan tetapi ini menjadi kendala Responden kedua untuk mengatur waktu antara kerja dan kuliah online.

Bagi dosen, pembelajaran daring memiliki tantangan khusus, seperti lokasi mahasiswa dan dosen yang terpisah saat melaksanakan pembelajaran menyebabkan dosen tidak dapat mengawasi secara langsung kegiatan mahasiswa selama proses pembelajaran. Tidak ada jaminan bahwa mahasiswa sunguh-sungguh dalam mendengarkan ulasan dari dosen.

Selanjutnya Responden ketiga mengungkapkan bahwa ia sebenarnya terpaksa mengikuti pembelajaran daring karena keadaan pandemi COVID-19 dan kesulitan mengimbangi karena materi kuliah yang dianggapnya sulit. COVID-19 yang datang tiba-tiba dan pengaruhnya dalam segala sektor kehidupan termasuk pendidikan sangat cepat mendesak mahasiswa siap dengan kebijakan-kebijakan yang ada meskipun pada akhirnya ada yang terpaksa seperti yang diungkapkan responden ketiga.

Kemudian juga Responden keempat yang mengungkapkan bahwa metode pembelajaran daring baru terdengar di telinganya dan lebih senang jika perkuliahan berlangsung tatap muka karena bisa berinteraksi dengan kawankawannya. Sedikit banyak mahasiswa yang mengetahui istilah pembelajaran daring, responden keempat mengatakan bahwa ia baru mendengar istilah daring.

\section{Ketidaksiapan Dosen}

Peneliti memberikan pertanyaan kepada subjek penelitian mengenai kesulitan atau kendala mereka terhadap metode belajar yang disampaikan dosen dalam pelaksanakan pembelajaran daring di perguruan tinggi. 
Tabel 3. Hasil Wawancara Tentang Kesiapan Dosen

Responden 1: "kadang materinya mudah dipahami, kadang jadi sulit. Penjelasan dari dosen harusnya lebih banyak lagi biar semua materi jelas jadi mudah dipahami"

Responden 2: "saya tidak begitu memahami penjelasan dosen karena bentuknya hanya file PDF, harusnya dosen tambahkanlah video biar jelas langkah-langkah pengerjaannya, seringnya setelah dapat materi dari dosen saya harus cari sendiri lagi di Youtube biar paham ngerjakannya!"

Responden 3: "Penjelasan dari dosen saya kurang paham, harusnya bapaknya ndak cuma pakai WhatsApp, tambahkan juga Zoom biar ada tatapmuka, biar ada tutorial cara membuktikan soal-soal tugas itu. Kalau Cuma baca dari PDF, sulit... Mudahmudahan ada Zoom atau paling gak video pembuktian soal lah..."

Dapat kita perhatikan pada tabel, responden pertama mengungkapkan bahwa dosen kurang cukup dalam menyampaikan penjelasan terkait dengan materi sehingga terkadang materi tersebut menjadi sulit untuk dipahami. Penelitian Sun et al., (2008) menginformasikan, bahwa kepuasan mahasiswa terhadap pembelajaran dipengaruhi oleh fleksibilitas waktu, metode pembelajaran, dan tempat dalam pembelajaran daring.Jadi, dosen bisa saja memberikan perkuliahan melalui kelas-kelas virtual yang dapat diakses dimana pun dan kapan pun tidak terikat ruang dan waktu. Kondisi ini membuat mahasiswa dapat secara bebas memilih mata kuliah yang dikuti dan tugas mana yang harus dikerjakan lebih dahulu.

Responden kedua beranggapan dosen harusnya jangan hanya mengandalkan PDF materi pembelajaran tetapi menyediakan juga dalam video sehingga materi-materi terkait pembuktian bisa dapat diikuti langkah-langkah penyelesaiannya. Walaupun pembelajaran berlangsung daring mahasiswa mengharapkan dosen dapat mengemas penyampaian materi yang mudah dipahami bukan hanya lewat tulisan tapi juga bisa lewat gambar, video atau audio visual.

Responden Ketiga menganggap seharusnya dosen mampu menyajikan pembelajaran dengan media daring yang lain, tidak hanya terpaku pada WhatsApp. Ia menyarankan dosen untuk dapat menambahkan aplikasi Zoom 
Meeting yang memungkinkan dosen dan mahasiswa bertatap muka dan melakukan pembelajaran secara daring. Banyak jenis media daring yang bisa dimanfaatkan agar perkuliahan berlangsung menyenangkan walaupun tidak bertatap muka misalnya aplikasi zoom yang bisa dosen pakai sebagai alternatif media daring agar tetap bertatap muka dengan mahasiswa walaupun hanya virtual.

\section{KESIMPULAN}

Berdasarkan hasil pembahasan di atas dapat dijabarkan kesulitan-kesulitan yang dihadapi mahasiswaIAIN Syekh Nurjati Cirebon yaitu :

1) Kesulitan teknis, meliputi kesulitan sinyal internet, keterbatasan kuota internet dan perangkat pendukung,

2) Kesulitan adaptasi mahasiswa, yang meliputi keadaaan rumah tidak kondusif, tidak terbiasa kuliah daring, tugas daring lebih banyak, dan kesulitan membagi waktu,

3) Ketidaksiapan dosen, yang meliputi penjelasan yang masih kurang, terbatasnya bentuk materi yang diberikan dan terbatasnya aplikasi yang digunakan dosen dalam pembelajaran daring.

\section{REFERENCES}

Ali Sadikin, Afreni Hamidah. (2020) Pembelajaran daring di tengah wabah covid-19. 06/02. 214-224.

ArcGIS. "Indonesia COVID-19 Dashboard" Komite Penanganan COVID-19 dan Pemulihan Ekonomi Nasional. 21 Oktober 2020

Bangkok Post. "Indonesia confirms first cases of coronavirus"(dalam bahasa Inggris). Reuters. 2 Maret 2020. Diakses tanggal 2 Maret 2020.

Dewi, Wahyu Aji Fatma. 2020. Dampak Covid-19 Terhadap Implementasi Pembelajaran Daring Di Sekolah Dasar. Edukatif: Jurnal Ilmu Pendidikan. Volume 2 Nomor 1 Halm 55-61.

Fey. CNNIndonesia. (n.d.-b). 65 Kampus Kuliah Dari Rumah, Sultan Yogya Ragukan Efektivitas.

Retrieved from https://www.cnnindonesia.com/nasional/20200316110707-20-483756/65kampus-kuliah-dari-rumah-sultan-yogya-ragukan-efektivitas. diakses pada Juni 2020.

Firman \& Sari. (2020). Pembelajaran Online di Tengah Pandemi Covid-19. Indonesian Journal Of Educational Science (IJES), Volume 02 No 02. 
Firman, F., \& Rahayu, S. (2020). Pembelajaran Online di Tengah Pandemi Covid-19. Indonesian Journal of Educational Science (IJES), 2(2), 81-89

Hasan, B. (2020). Pemanfaatan Google Classroom Dalam Matakuliah Menggunakan Media Video Screencast O-Matic. Widya Wacana: Jurnal Ilmiah, 15(1), 9-15.

Hartanto, W. (2016). Penggunaan ELearning sebagai Media Pembelajaran. Jurnal Pendidikan Ekonomi, 10(1), 1-18.

https://eprints.uny.ac.id/9124/3/bab\%202\%20-04513241025.pdf

https://dinkes.bantulkab.go.id/berita/800-mengenal-covid-19 diakses pada 22 oktober 2020

Jamaluddin, D., Ratnasih, T., Gunawan, H., \& Paujiah, E. (2020). Pembelajaran daring masa pandemik Covid-19 pada calon guru: hambatan, solusi dan proyeksi. LP2M.

Menteri Pendidikan. (2020). Surat Edaran Nomor 3 Tahun 2020 Tentang Pelaksanaan Pendidikan dalam Masa Darurat CoronaVirus (COVID-19).

Moloeng, L. (2007). Metodologi Penelitian Kualitatif. Jakarta: Remaja Karya.

Mustakim. (2020). Efektivitas Pembelajaran Daring Menggunakan Media Online Selama Pandemi Covid-19 Pada Mata Pelajaran Matematika (the Effectiveness of E-Learning Using Online Media During the Covid-19 Pandemic in Mathematics). Al Asma: Journal of Islamic Education, 2(1), 1-12

Nakayama M, Yamamoto H, \& S. R. (2007). The Impact of Learner Characterics on Learning Performance in Hybrid Courses among Japanese Students. Elektronic Journal ELearning, Vol.5(3).1

Permata, J. I., \& Sandri, Y. (2020). Analisis Kemampuan Pemecahan Masalah Pada Siswa Smp Maniamas Ngabang. Riemann Research of Mathematics and Mathematics Education, 2(1), 10-22.

Purnamasari, D. M. (2020). Arahan Jokowi untuk Pemda: Liburkan Sekolah hingga TingkatkanLayananPasienCovid-19.Kompas.Com.

https://nasional.kompas.com/read/2020/03/15/14452291/arahan-jokowi-untukpemda-liburkansekolah-hingga-tingkatkan-layanan-pasien

Prayitno P. (2020). IAIN Syekh Nurjati Cirebon Terapkan Sistem Kuliah Online selama $14 \quad$ Hari. https://www.liputan6.com/regional/read/4202630/iain-syekh-nurjati-cirebonterapkan-sistem-kuliah-online-selama-14-hari

Prawiradilaga, Salma, dkk. 2016. Mozaik Teknologi Pendidikan: Elearning.Jakarta: Prenadamedia Group.

Ratcliffe, Rebecca (2 Maret 2020). "First coronavirus cases confirmed in Indonesia amid fearsnation is ill-prepared for an outbreak". The Guardian (dalam bahasa Inggris). Diakses tanggal 2 Maret 2020

WahyuAji, F. D. (2020). Dampak Covid-19 terhadap Implementasi Pembelajaran Daring di Sekolah Dasar, Vol 2, 55-61 
Worldometer "Coronavirus Update Worldwide" (dalam bahasa Inggris). Diakses tanggal 21 Oktober 2020.

Yurianto, Ahmad, dkk. (2020). PEDOMAN PENCEGAHAN DAN PENGENDALIAN CORONAVIRUS DISEASE (COVID-19) (M. I. Listiana Azizah, Adistikah Aqmarina (ed.)). 